\title{
Green Financing for Carbon-Free Growth: Role of Banks Marketing Strategy
}

http://doi.org/10.21272/fmir.5(3).71-78.2021

Tetyana Pimonenko, ORCID: https://orcid.org/0000-0001-6442-3684

Dr.Sc., Associate Professor, Sumy State University, Ukraine

Yana Us, ORCID: https://orcid.org/0000-0003-1451-0450

Sumy State University, Ukraine

Yuliya Myroshnychenko, ORCID: https://orcid.org/0000-0002-0463-0347

Ph.D., Associate Professor, Sumy State University, Ukraine

Olexiy Dubyna,

Sumy State University, Ukraine

Tetyana Vasylyna, ORCID: https://orcid.org/0000-0002-6957-0082

Sumy State University, Ukraine

\begin{abstract}
Nowadays, the climate change problems are on the international agenda, while increasing attention is paid to the role of green finance and bank activity in developing a climate-neutral future. This paper aims to investigate the scientific background devoted to bank marketing to determine the role of green finance in carbon-free economic growth and identify the potential research directions under this issue. The systematization of scientific publications presented in the Scopus database showed the growing tendency in publication activity concerning bank marketing and carbon-free economic growth. However, the scientific problem is a gap in studies devoted to investigating the role of financial marketing strategies in the bank sector for intensifying carbon-free economic growth. To gain the research goal, the authors conducted the bibliometric analysis using the VOSviewer software tools. Methodological tools of the research were the method for visualizing similarities between keywords. This study operates with the scientific articles published in the journals indexed in the Scopus database. The research period is 2000-2020. The research theoretically proved that green finance is one of the main triggers of carbon-free development. The obtained results of the bibliometric analysis identified four main research directions concerning the investigated topic such as 1) financial marketing in sustainable development; 2) financial management in environmental protection; 3) carbon markets; 4) international regulation in emission trading. The authors determined the contribution of scientists in developing the investigated issues. Most productive journals were highlighted. The findings determined the pioneer countries in exploring the analyzed topic. The current study findings are limited by the articles presented only in the Scopus database. Therefore, future research should expand the study sample to compare the articles presented in other reliable scientific databases such as the Web of Science.
\end{abstract}

Keywords: bank marketing, carbon market, carbon-free development, green finance, marketing strategy.

JEL Classification: G30, Q56, Q53, Q51.

Cite as: Pimonenko, T., Us, Ya., Myroshnychenko, Yu., Dubyna, O., Vasylyna, T. (2021). Green Financing for Carbon-Free Growth: Role of Banks Marketing Strategy. Financial Markets, Institutions and Risks, 5(3), 71-78. http://doi.org/10.21272/fmir.5(3).71-78.2021

Received: 18, July, 2021

Accepted: 7, September, 2021

Published: 13, September, 2021

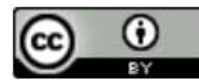

Copyright: (C) 2021 by the authors. Licensee Sumy State University, Ukraine. This article is an open access article distributed under the terms and conditions of the Creative Commons Attribution (CC BY) license (https://creativecommons.org/licenses/by/4.0/)

\section{Introduction}

Nowadays, climate change issues are on the agenda. The consumption of hydrocarbon resources galvanizes the growth of $\mathrm{CO} 2$ emissions. Therefore, the above affects environmental stability with devastating 
consequences. The international community declares the severity of climate change and the necessity to adapt economic, political, organizational, and legal measures to reduce and optimize the anthropogenic impact.

Following the above, the investigation of current international measures is highly relevant in overcoming and mitigating greenhouse gas emissions worldwide. It stands to note that in 2005 , the Kyoto Protocol to the UN Framework Convention on Climate Change introduced the carbon market as an innovative mechanism towards reducing environmental emissions (Lyulyov et al., 2021). Remarkably, the carbon market is one of the effective climate mitigation tools in regulating $\mathrm{CO} 2$ and other greenhouse gas emissions. Recently, the $\mathrm{CO} 2$ regulation has become an essential component of international climate policy and the national energy, economic and technological policies.

It stands to note that the pollution credit under the Kyoto Protocol obligates the signatory states to reduce the greenhouse gases due to trading or repurchasing emissions. The Paris Agreement under the United Nations Framework Convention on Climate Change suggests that specific measures to overcome climate change should reduce greenhouse gas emissions. Besides, the countries are obligated to develop specific national measures and meet them. Therefore, the Paris Agreement established the transition toward carbon-free economic development (Us et al., 2020; Tambovceva et al., 2020). In turn, it provides the gradual refusal of traditional producing, processing, and using fossil resources for the account of green technologies.

Thus, carbon-free economic development, emission reduction, and regulation are under focus not only on international climate policy. Most developed and developing countries consider carbon-neutrality a significant competitive advantage on the global market (Palienko et al., 2017) and an effective tool to raise investments into modernization and innovations (Chygryn, 2017; Pimonenko et al., 2018; Pimonenko et al., 2019b).

While the interest in carbon-free economic development and carbon trade raises, the banks pay more attention to environmental, social, and administrative issues (Mursalov, 2020). They diversify their bank product range, focusing on socially responsible products. Indeed, financial institutions would be instrumental in carbon-free economic transformation. Thus, banks have started to move towards increasing their green reputation to protect their funds. Remarkably, the investments into fossil fuels are expected to become the dead equity. Therefore, the good bank marketing strategy attracts green and socially responsible clients and stakeholders while contributing to carbon-free economic development.

\section{Literature Review}

The analysis of scientific papers on bank marketing and carbon-free economic growth presented in the Scopus database showed the growing interest among the scientists in these topics. Figure 1 demonstrates the treatise of scientific articles devoted to bank marketing (3854 publications) is higher than those focused on carbonfree economic growth (2556 publications) for 2000-2020. However, since 2019, scientists have become more interested in carbon-free economic issues. Remarkably, it could be caused by introducing the European Green Deal in 2019, which calls for gaining climate neutrality in the EU until 2050.

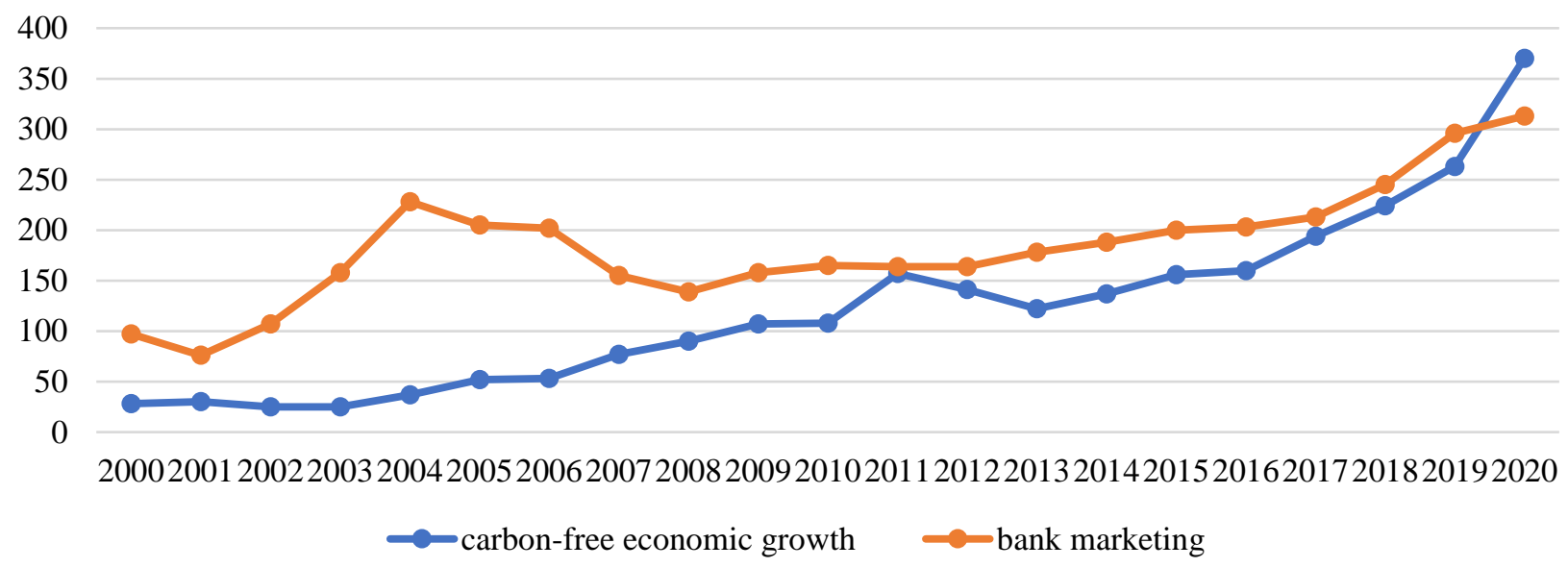

Figure 1. The comparison of publication activity dynamic on bank marketing and carbon-free economic growth, 2000-2020 
Srinivasa Rao et al. (2020) highlighted that the world is greening. Many companies worldwide recognize the green customers' needs addressed to environment protection (Pimonenko et al., 2019a; Hussain et al., 2020; Chygryn and Scherbak, 2011; Pimonenko et al., 2019b). Therefore, the scientists determined the 'going green' approach in the banking sector to be a prospective direction in developing a carbon-free future. Herewith, many articles are devoted to examining the green brand image in the banking sector. The Turkish researchers Ibe-enwo et al. (2019) considered the marketing perspectives in green banking practice. The authors concluded that green banking activities increase bank loyalty and attract interest to environmental issues. In the studies (Nguyen and Nguyen, 2018), the authors indicated that green bank equity could be enhanced due to improving the main components of the green marketing scale, such as the development of the green product, strengthening green corporate social responsibility, and intensifying the green internal process in a bank.

The Indian researcher Singh (2015) explored the role of green banking in environmental management. The author confirmed the bank activity's contribution to environmental welfare. Besides, the scientist categorized the main phases of green marketing operations in the bank activity.

Abdur Rouf (2012) concluded that microfinance and renewable energy programs contribute to economic and green development. In turn, the researcher emphasized the importance of developing effective bank marketing strategies to promote green micro-financing and green micro-business growth.

The preliminary scientific treatises analysis showed many publications devoted to a carbon-free economy and bank marketing strategies. However, there is still a gap in investigating the role of financial marketing strategies in the bank sector for carbon-free economic growth. Therefore, this study aims to conduct a bibliometric analysis to determine the linkage between bank marketing strategies, green finance, and carbonfree development.

\section{Methodology and research methods}

This study operates with the scientific articles published in the journals indexed in the Scopus database. The research period is 2000-2020. The paper aims to investigate the linkage between bank marketing strategies and a carbon-free economy to determine the role of green finance in carbon-free economic growth and identify the potential research directions under this issue.

The analysis of the role of bank marketing strategies in carbon-free growth faces some methodological and analytical restrictions since a lack of full and relevant statistical data to estimate the contribution of green financing in carbon-free economic development. Besides, there is a risk of losing the topicality since scientific papers are published with some time delay. Therefore, this study involved the bibliometric analysis following the methodology proposed in the papers (Bilan et al., 2020; Dubina et al., 2020; Akhundova et al., 2020) to achieve the research goal. Following the above, this study presents the findings on evaluation analysis by the metrics of publication activity, journals, countries, authors, institutions, and funding sponsors. For determining the potential research directions, the method for visualization of similarities was applied.

It stands to note that there is a diversity of meaning for a carbon-free economic growth (such as no carbon, carbon-neutral, zero carbon, free of carbon, climate positive, carbon neutrality, etc.). Thus, the combinations of the above synonyms with keyword phrased 'bank or finance marketing' were applied to form the study sample.

The search of articles by the above keyword phrases was conducted in the titles, abstracts, and keywords. The obtained results were limited by the subject areas: Business, Management and Accounting, Energy, Social Sciences, and Economics, Econometrics and Finance. Besides, the bibliometric analysis dealt only with scientific articles written in English.

\section{Results}

With the purpose to analyze the role of banks' marketing strategy in financing carbon-free growth, the cooccurrence analysis included the articles indexed by different definitions describing carbon-free development (such as carbon, green, carbon-free, no carbon, carbon-neutral, zero carbon, free of carbon, carbon-neutral, climate-neutral) and bank marketing. Figure 2 visualizes the obtained results. 


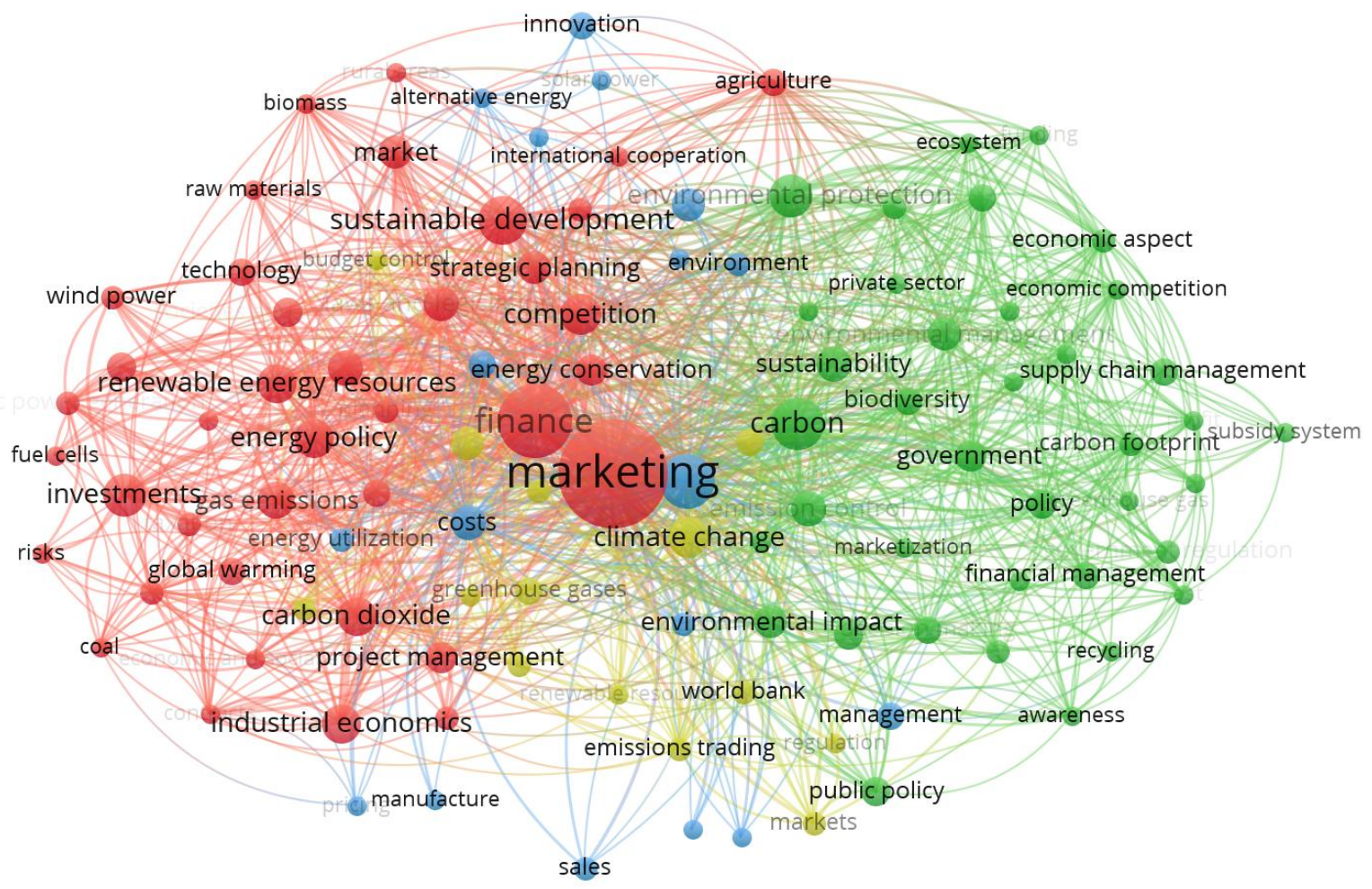

Figure 2. Network visualization the linkages between bank marketing and carbon-free growth

Sources: developed by the authors based on the Scopus data (2021) using VOSviewer tools.

The findings indicated the strong linkages between carbon-free development and financial services marketing (1687 linkages with total link strength of 2716). Therefore, it could be concluded that banks employ different financial services marketing techniques to support and contribute to carbon-free development. The keyword network determines four main directions the scientist concentrated on: 1) financial marketing in sustainable development; 2) financial management in environmental protection; 3) carbon markets; 4) international regulation in emission trading.

The most significant cluster is red. It consists of 39 items primarily focused on exploring the financial marketing tools in sustainable development. Besides, it stands to note the strong link strength (31) between keywords finance and marketing. These couple of keywords occurred mainly in the analyzed scope of articles. Therefore, in 2000-2020, the scientists primarily were concentrated on exploring the finance marketing mechanism to boost the carbon trade.

The second cluster (green) consists of 39 keywords determining the significant role of financial management in environmental protection. Thus, the cluster combines the works devoted to analyzing carbon emissions, their environmental impact, and their influence on the economy. Subsequently, the third (blue) and fourth (yellow) clusters are massively smaller. The blue cluster consists of 18 items focused on green marketing and financing mechanisms in developing carbon markets. The fourth cluster combines 14 keywords. This cluster indicates the research interests in analyzing emission trading regulation on the international level under growing renewable energy. 


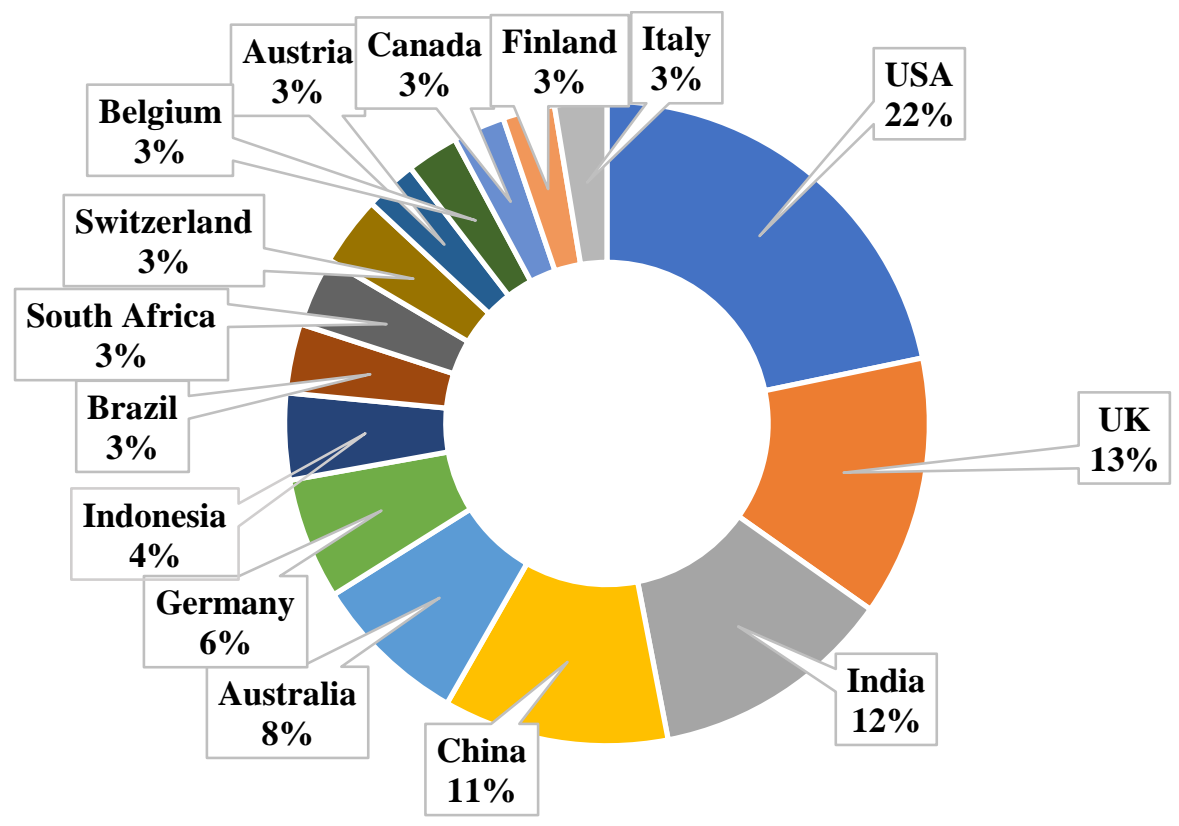

Figure 3. TOP-15 countries researching the role of bank marketing in carbon-free growth

Sources: developed by the authors based on the Scopus data (2021) using VOSviewer tools.

Figure 3 demonstrates that the USA is a clear leader in publication activity on the investigated topic. Thus, the contribution of the scientist from the USA is $22 \%$. In turn, there is a slight difference in the shares of scientific articles from the UK (13\%), India (12\%), and China (11\%). Besides, the shares of articles by Australia is $8 \%$ and Germany $-6 \%$. The rest of the countries' contributions are less than $5 \%$.

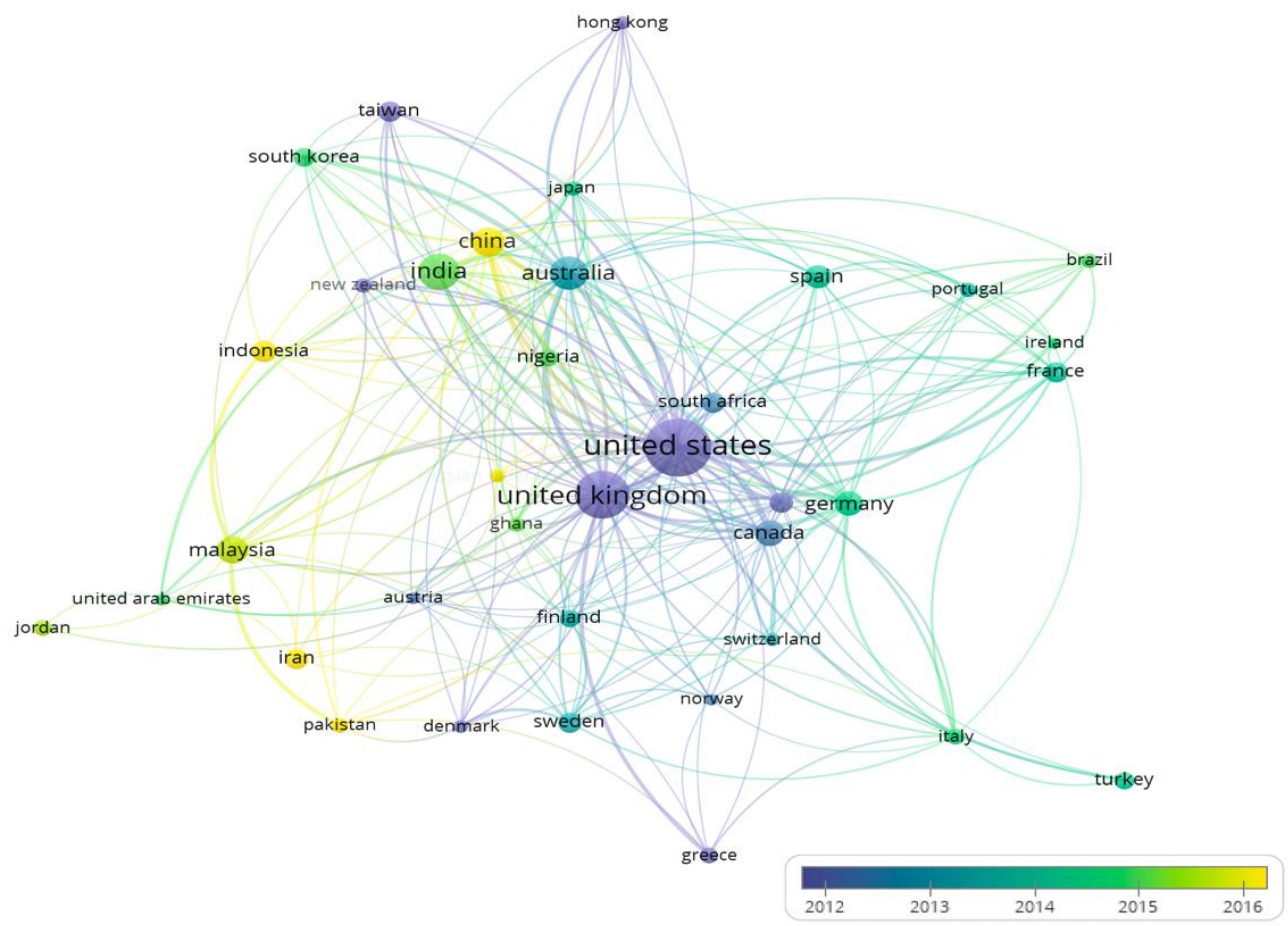

Figure 4. The overlay visualization of the authors' collaboration

Sources: developed by the authors based on the Scopus data (2021) using VOSviewer tools.

Figure 4 shows six main periods of studying bank marketing and carbon-free growth. The first period relates the articles published until 2012. Thus, scientists from the USA, UK, Greece, Germany, Taiwan, New Zealand, and Hong Kong could be considered pioneers in investigating the analyzed topic. The second period is dated as of 2012-2013. The researchers from Canada, Australia, South Africa, Norway, Austria, etc., followed this research direction. In 2013-2014, researchers from Spain, Ireland, Brazil, Portugal, France, Italy, Turkey, Sweden, 
Finland, etc. The scientists from the United Arab Emirates, India, South Korea, Brazil, etc., were most active. The fifth period is dated as of 2015-2016, while the scientists from Malaysia, Jordan joining to research. Since 2016, mainly Chinese, Indonesian, Iranian, and Pakistanian scientists have focused on research the analyzed issues.

It stands to note that most papers were published in the high-ranked scientific journals as follows:

$>$ Energy Policy (UK/Q1);

$>$ International Journal of Environmental Research And Public Health (Switzerland/Q2):

$>$ HPAC Heating Piping Airconditioning Engineering (USA/Q4);

> Journal of Cleaner Production (UK/Q1);

$>$ Sustainability Switzerland (Switzerland/Q1), etc.

To determine the most influential works and authors, Table 1 systemized TOP-10 articles by the number of citations in the Scopus database from 2000 to 2020.

Table 1. TOP-10 influential articles on the investigated topic, 2000-2020

\begin{tabular}{|c|c|c|c|c|c|}
\hline No & $\begin{array}{c}\text { Title } \\
\end{array}$ & Authors & Journal & Year & Citation \\
\hline 1 & $\begin{array}{l}\text { Resources and capabilities as drivers of } \\
\text { hotel environmental marketing strategy: } \\
\text { Implications for competitive advantage } \\
\text { and performance }\end{array}$ & $\begin{array}{l}\text { Leonidou, L.C., Leonidou, } \\
\text { C.N., Fotiadis, T.A., Zeriti, A. }\end{array}$ & $\begin{array}{c}\text { Tourism } \\
\text { Management }\end{array}$ & 2013 & 191 \\
\hline 2 & $\begin{array}{l}\text { Enablers and barriers to large-scale } \\
\text { uptake of improved solid fuel stoves: A } \\
\text { systematic review }\end{array}$ & $\begin{array}{l}\text { Rehfuess, E.A., Puzzolo, E., } \\
\text { Stanistreet, D., Pope, D., } \\
\text { Bruce, N.G. }\end{array}$ & $\begin{array}{l}\text { Environmental } \\
\text { Health } \\
\text { Perspectives }\end{array}$ & 2014 & 172 \\
\hline 3 & $\begin{array}{l}\text { Designing a mixed performance } \\
\text { measurement system for environmental } \\
\text { supply chain management using } \\
\text { evolutionary game theory and balanced } \\
\text { scorecard: A case study of an auto } \\
\text { industry supply chain }\end{array}$ & $\begin{array}{l}\text { Jalali Naini, S.G., Aliahmadi, } \\
\text { A.R., Jafari-Eskandari, M. }\end{array}$ & $\begin{array}{l}\text { Resources, } \\
\text { Conservation } \\
\text { and Recycling }\end{array}$ & 2011 & 103 \\
\hline 4 & $\begin{array}{l}\text { Visually branding the environment: } \\
\text { Climate change as a marketing } \\
\text { opportunity }\end{array}$ & Hansen, A., MacHin, D. & $\begin{array}{l}\text { Discourse } \\
\text { Studies }\end{array}$ & 2008 & 95 \\
\hline 5 & $\begin{array}{l}\text { Lignin, potential products and their } \\
\text { market value }\end{array}$ & $\begin{array}{l}\text { Ludmila, H., Michal, J., } \\
\text { Andrea, Š., Aleš, H. }\end{array}$ & $\begin{array}{l}\text { Wood } \\
\text { Research }\end{array}$ & 2015 & 79 \\
\hline 6 & $\begin{array}{l}\text { The development and market success of } \\
\text { eco-innovations: A comparative study of } \\
\text { eco-innovations and "other" innovations } \\
\text { in Sweden }\end{array}$ & Halila, F., Rundquist, J. & $\begin{array}{c}\text { European } \\
\text { Journal of } \\
\text { Innovation } \\
\text { Management }\end{array}$ & 2011 & 73 \\
\hline 7 & $\begin{array}{l}\text { Sustainability entrepreneurship and } \\
\text { equitable transitions to a low-carbon } \\
\text { economy }\end{array}$ & Parrish, B.D., Foxon, T.J. & $\begin{array}{l}\text { Greener } \\
\text { Management } \\
\text { International }\end{array}$ & 2006 & 69 \\
\hline 8 & $\begin{array}{l}\text { Managing permit markets to stabilize } \\
\text { prices }\end{array}$ & $\begin{array}{c}\text { Newell, R., Pizer, W., Zhang, } \\
\text { J. }\end{array}$ & $\begin{array}{l}\text { Environmental } \\
\text { and Resource } \\
\text { Economics }\end{array}$ & 2005 & 65 \\
\hline 9 & $\begin{array}{l}\text { Disagreement over carbon footprints: A } \\
\text { comparison of electric and LPG forklifts }\end{array}$ & Johnson, E. & Energy Policy & 2008 & 50 \\
\hline 10 & $\begin{array}{l}\text { Detection of Insect Infestation in Stored } \\
\text { Foods }\end{array}$ & Rajendran, S. & $\begin{array}{l}\text { Advances in } \\
\text { Food and } \\
\text { Nutrition } \\
\text { Research }\end{array}$ & 2005 & 45 \\
\hline
\end{tabular}

*Source: developed by the authors based on (Scopus, 2021).

Remarkably, the collaborative paper by Leonidou L.C. (Cyprus), Leonidou C.N. (UK), Fotiadis T.A. (Cyprus), Zeriti A. (UK) (Leonidou et al., 2013) published in the scientific journal 'Tourism Management' is the most reliable among the analyzed papers. In this paper, the authors primarily concentrated on investigating environmentally friendly strategies in the hotel sector. The authors built the model confirming that financial resources are one of the main instruments in green growth. Thus, it indicates the necessity to focus on investigating the financial marketing strategies in more detail. 
The paper by Rehfuess E.A. (Germany), Puzzolo E. (UK), Stanistreet D. (UK), Pope D. (UK), and Bruce N.G. (UK) (Rehfuess et al., 2014) has a little bit fewer citations (172). Among the analyzed factors influencing the introduction of energy-efficient projects. In turn, the authors emphasized the significant effect of marketing in attracting green finance.

Table 2. The TOP-10 keywords with the greatest total strengths of the co-occurrence links

\begin{tabular}{|c|l|c|c|}
\hline No & \multicolumn{1}{|c|}{ Keyword } & Occurences & Total link \\
\hline 1 & Marketing & 79 & 578 \\
\hline 2 & Finance & 38 & 299 \\
\hline 3 & Carbon & 19 & 299 \\
\hline 4 & Commerce & 21 & 165 \\
\hline 5 & Environmental protection & 13 & 140 \\
\hline 6 & Sustainable development & 16 & 124 \\
\hline 7 & Renewable energy resources & 11 & 113 \\
\hline 8 & Climate change & 12 & 113 \\
\hline 9 & Energy policy & 11 & 110 \\
\hline 10 & Emission control & 9 & \\
\hline
\end{tabular}

Sources: systemized by the authors based on the Scopus data (2021).

Table 2 presents the most influential keywords in the scope of the analyzed articles. Therefore, the keyword 'marketing' has the most significant total link (578), while it occurred 79 times. In turn, the keyword 'finance' is in second place. It appeared 38 times, while the total link strength with other keywords is 299. Remarkably, the total link strength of the keyword 'carbon' is 299 too. However, it occurred approximately two times less than the previous one. Table 2 concludes that financial marketing was directed toward promoting carbon trade and decreasing the emission burden due to renewable energy.

\section{Conclusions}

The findings of bibliometric analysis confirmed the linkages between green finance in carbon-free economic growth. The obtained results of co-occurrence analysis showed four main research directions concerning the investigated topic such as 1) financial marketing in sustainable development; 2) financial management in environmental protection; 3) carbon markets; 4) international regulation in emission trading.

However, there is a limited amount of articles devoted to marketing in banks. Thus, the role of marketing bank strategy is still undeveloped well in scientific circles. Besides, the current study limitations could be the narrow keywords combinations and investigating the articles presented only in the Scopus database. Therefore, expanding the study sample and comparing the articles presented in other reliable scientific databases such as the Web of Science is appropriate for further researches.

\section{Author Contributions}

Conceptualization: Pimonenko, T.; methodology: Pimonenko, T. and Us, Ya.; software: Us, Ya.;. and O.D.; validation: Pimonenko, T.; formal analysis: I.M; investigation: Us, Ya. and Myroshnychenko, Yu.; resources: Us., Ya.; data curation, Dubyna, O.; writing-original draft preparation: Us, Ya.;. writing-review and editing: T.P.; visualization: Us., Ya. and Dubyna, O.; supervision: Pimonenko, T.; project administration: Pimonenko, T.; funding acquisition: Pimonenko, T.

\section{Funding}

This research was funded by National Research Foundation of Ukraine "Stochastic modelling of road map for harmonizing national and European standards for energy market regulation in the transition to a circular and carbon-free economy", $0120 \mathrm{U} 104807$.

\section{References}

1. Abdur Rouf, K. (2012). Green microfinance promoting green enterprise development. Humanomics, 28(2), 148-161. [Google Scholar]

2. Akhundova, N., Pimonenko, T., Us, Ya. (2020). Sustainable growth and country green brand: visualization and analysis of mapping knowledge (Book of Proceedings), 55th International Scientific Conference on Economic and Social Development - "Economic and Social Development", Baku, 18-19, 234-243. [Link] 
3. Bilan, Y., Pimonenko, T., \& Starchenko, L. (2020). Sustainable business models for innovation and success: bibliometric analysis. In E3S Web of Conferences, 159, 04037. EDP Sciences. [Google Scholar]

4. Chygryn, O. (2017). Green entrepreneurship: EU experience and Ukraine perspectives. Centre for Studies in European Integration Working Papers Series, 6, 6-13. [Google Scholar]

5. Chygryn, O.Yu., \& Scherbak, A.S. (2011). Analysis of the problem of the introduction the environmentally friendly production in Ukraine. The mechanism of economic regulation, 1, 235-241. [Link]

6. Dubina, O., Us, Y., Pimonenko, T.,\& Lyulyov, O. (2020). Customer Loyalty to Bank Services: The Bibliometric Analysis. Virtual Economics, 3(3), 52-66. [CrossRef]

7. Hussain, S. A., Haq, M. A. U., \& Soomro, Y. A. (2020). Factors Influencing Consumers' Green Purchase Behavior: Green Advertising as Moderator. Marketing and Management of Innovations, 4, 144-153. [CrossRef]

8. Ibe-enwo, G., Igbudu, N., Garanti, Z., \& Popoola, T. (2019). Assessing the relevance of green banking practice on bank loyalty: The mediating effect of green image and bank trust. Sustainability (Switzerland), 11(17). [Google Scholar]

9. Leonidou, L. C., Leonidou, C. N., Fotiadis, T. A., \& Zeriti, A. (2013). Resources and capabilities as drivers of hotel environmental marketing strategy: Implications for competitive advantage and performance. Tourism Management, 35, 94-110. [Google Scholar]

10. Lyulyov, O., Pimonenko, T., Kwilinski, A., \& Us, Y. (2021). The heterogeneous effect of democracy, economic and political globalisation on renewable energy. In E3S Web of Conferences, 250, 03006). EDP Sciences. [Google Scholar]

11. Mursalov, M. (2020). Banking Regulations and Country's Innovative Development: the Mediating Role of Financial Development. Marketing and Management of Innovations, 4, 168-180. [CrossRef]

12. Nguyen, N. T. H., \& Nguyen, D. T. N. (2018). Impacts of green marketing on the green brand image and equity in banking sector. WSEAS Transactions on Business and Economics, 15, 452-460. [Link]

13. Pimonenko, T., Liuliov, O., \& Us, Y. (2019a). Marketing strategies of green investments: basic concepts and specific features. Herald of Ternopil National Economic University, 1(91), 177-185. [Google Scholar]

14. Pimonenko, T., Lyulyov, O., Chygryn, O. (2018). Marketing of green investment: collaboration between main stakeholders. Reporter of the Priazovskyi State Technical University. Section: Economic sciences, 36, 214-220. [Google Scholar]

15. Pimonenko, T., Lyulyov, O., Us, Ya. (2019b). Marketing strategies of green investments: main provisions and basic features. Herald of Ternopil National Economic University, (1), 177-185. [CrossRef]

16. Rehfuess, E. A., Puzzolo, E., Stanistreet, D., Pope, D., \& Bruce, N. G. (2014). Enablers and barriers to large-scale uptake of improved solid fuel stoves: A systematic review. Environmental Health Perspectives, 122(2), 120-130. [Google Scholar]

17. Singh, Y. (2015). Environmental management through green banking: A study of commercial banks in india. Journal of Interdisciplinary and Multidisciplinary Research, 2(4), 17-26. [Link]

18. Tambovceva, T., Urbane, V., \& Levins, J. (2020). Innovations in Construction Waste Management: Case of Latvia. Marketing and Management of Innovations, 3, 234-248. [CrossRef]

19. Us, Ya., Pimonenko, T., Lyulyov, O. (2020). Energy efficiency profiles in developing the free-carbon economy: on the example of Ukraine and the V4 countries, Polityka Energetyczna - Energy Policy Journal, 23(4), 49-66. [CrossRef] 